Relatorio

\title{
GALICIA FRONTE Á GLOBALIZACIÓN
}

Guillermo de la Dehesa

Centre for Economic Policy Research, CEPR, London 



\section{INTRODUCIÓN}

O proceso de crecente globalización non é un fenómeno novo, xa que houbo outra gran vaga globalizadora entre 1870 e 1913 . A súa orixe está na redución progresiva dos custos de transporte dos bens, servizos, persoas, ideas e información derivados dos progresos tecnolóxicos que permiten que os medios de transporte sexan cada vez máis rápidos e baratos. Isto fixo que se desenvolvese primeiro o comercio nacional e internacional e, máis tarde, que houbese unha deslocalización crecente daquelas partes dos procesos produtivos que precisaban máis man de obra a outras rexións e países menos desenvolvidos e con custos laborais máis baixos. Finalmente, este fenómeno viuse favorecido polo feito de que unha parte cada vez maior dos servizos poidan subministrarse a distancia grazas aos ordenadores e a Internet e á enorme caída dos prezos das telecomunicacións que os transportan. Así mesmo, a diminución dos custos de transporte das persoas está a provocar que aumenten notablemente os fluxos migratorios entre países que acadan xa o $10 \%$ da poboación total nas nacións da OCDE.

Por unha banda, a globalización significa que se asignan cada vez máis eficientemente os factores de produción mundiais alí onde teñen unha maior produtividade e rendibilidade. $\mathrm{O}$ traballo tende a migrar desde os países onde máis abonda e se perciben menores salarios a aqueles en que é máis escaso e se poden obter maiores salarios que no seu país de orixe. O capital adoita dirixirse desde os países desenvolvidos, onde é máis abundante, a aqueles onde é máis escaso e ten unha maior rendibilidade en relación co seu risco. O mesmo ocorre coa tecnoloxía e o coñecemento. Conséguese con iso que o capital sexa máis barato nos países onde antes era caro, que a produción sexa máis eficiente, cunha meirande produtividade e menores custos e un crecemento mundial maior. É dicir, sae gañando a meirande parte dos habitantes do mundo en tanto que son consu- 
midores, xa que os prezos máis baixos lles permiten consumir máis coa mesma ou menor renda e endebedarse con tipos de interese máis baixos para investir no seu capital humano e a súa saúde, e así prosperar.

\section{QUEN GAÑA E QUEN PERDE COA GLOBALIZACIÓN?}

Por outra banda, a globalización aumenta a competencia mundial, non só entre países desenvolvidos, senón, e especialmente, entre países emerxentes. Nun mercado internacional globalizado, seguirá a funcionar a teoría da vantaxe comparativa dun país concreto e dun sector determinado dentro de cada país. Cada un deles tenderá a especializarse naqueles bens e servizos en que teña non só unha vantaxe absoluta, senón tamén comparativa. Un país pode mesmo chegar a ter unha vantaxe absoluta en todos os bens e servizos que produce, pero, aínda nese caso, tenderá a especializarse naquel en que a súa vantaxe comparativa sexa maior en relación cos demais e deixará que outros países se especialicen no resto, xa que será así moito máis eficiente e terá un maior retorno por unidade producida e intercambiada.

O que ocorre, como xa se dixo, é que, na actualidade, unha boa parte do comercio mundial se leva a cabo dentro do mesmo sector industrial ou de servizos e incluso dentro da mesma empresa multinacional, entre a matriz e as súas filiais no estranxeiro ou entre as súas propias filiais, xa que a meirande parte do comercio non está baseada en bens finais, senón en partes e procesos do produto final, fabricándose cada un deles no país que ten unha maior vantaxe comparativa relativa.

Segundo a vantaxe comparativa revelada, podemos determinar os bens e servizos que saen gañando e os que resultan prexudicados nos países desenvolvidos. Dentro de cada país desenvolvido, a competencia será moi dura por parte dos países emerxentes naqueles bens e servizos produtivos substitutivos e onde os devanditos países emerxentes teñan unha clara vantaxe comparativa. Pola contra, a competencia será menor ou positiva naqueles bens e servizos que sexan complementarios e onde os países emerxentes se atopen cunha desvantaxe comparativa. No caso dos bens, a incorporación dos países emerxentes á globalización reforza a vantaxe comparativa dos países da UE nos seguintes sectores, por 
orde de maior a menor vantaxe comparativa: produtos farmacéuticos, enxeñaría mecánica, produción e subministro de electricidade, gas e auga, impresión e publicación, aeronáutica e aeroespacial, instrumentos científicos, papel, polpa e os seus produtos, produtos químicos, plásticos, vehículos de motor, maquinaria eléctrica e bebidas e tabaco.

Pola contra, os bens en que a vantaxe comparativa é maior nos países emerxentes son os seguintes, por orde de maior a menor vantaxe: aparatos receptores de televisión e radio, pesca, minaría e cantaría, válvulas electrónicas e tubos, maquinaria de oficina, agricultura e bosques, confección téxtil, cables, outros instrumentos, produtos de madeira e cortiza, metais básicos, estaleiros, equipos de telecomunicación, refinado de petróleo e carbón, equipo de ferrocarril e transporte, téxtiles, xoguetes e pel e calzado. No tocante aos servizos, na súa meirande parte teñen vantaxe comparativa revelada os países desenvolvidos nos seguintes: servizos financeiros e seguros, outros servizos profesionais, transportes e comunicacións, construción, viaxes, royalties e licenzas. Non obstante, perden vantaxe comparativa revelada os servizos de computación e información, por mor da gran vantaxe adquirida pola India.

Naturalmente, os sectores en que os países desenvolvidos teñen máis vantaxe comparativa revelada son os que requiren un maior nivel de capital humano, de innovación e de coñecemento e que xeran máis valor engadido. Estes, na súa meirande parte, están localizados nos EE UU, Alemaña, Reino Unido, Francia, os países nórdicos e Irlanda. Pola contra, os que mostran unha menor vantaxe comparativa revelada fronte aos países emerxentes tenden a estar localizados no sur de Europa e entre os novos países membros do leste de Europa. Bélxica, Holanda e Austria atópanse nunha zona máis neutra.

O mesmo que dos países e sectores en competencia pódese dicir dos cidadáns do mundo que compiten entre si, onde pode haber gañadores e perdedores. Para iso, convén distinguir entre os devanditos cidadáns a aqueles que viven maioritariamente das rendas do capital, é dicir, os capitalistas, e os que o fan das rendas do traballo, é dicir, os traballadores, e diferenciar entre estes últimos a aqueles que están máis cualificados e os que menos. De xeito excesivamente simplista, podemos dicir que os capitalistas dos países desenvolvidos adoitan saír favorecidos, posto que poden diversificar os seus investimentos nos países emerxentes, aumentando a súa rendibilidade e reducindo o seu risco cíclico medio 
ou, se son empresarios, poden explotar as grandes oportunidades de negocio que lles ofrece a globalización.

Os traballadores cualificados dos países desenvolvidos adoitan saír gañando porque se poden adaptar con máis rapidez e facilidade ás novas tecnoloxías da información e a comunicación, falan varios idiomas e poden emigrar ao país que mellor lles pague por exercer a súa profesión. Os traballadores pouco cualificados dos países desenvolvidos son os grandes prexudicados, xa que son apartados dos seus traballos rutineiros por robots ou por novas TIC e tamén porque teñen que competir indirectamente cos traballadores pouco cualificados dos países menos desenvolvidos a través dos bens e servizos importados, con prezos máis competitivos, ou directamente cos inmigrantes de baixa cualificación que acoden aos seus países. Tamén poden saír perdendo algunhas profesións de traballadores máis cualificados de servizos susceptibles de se subministrar a distancia.

Os capitalistas dos países en vías de desenvolvemento adoitan saír perdendo xa que conseguen rendibilidades moi elevadas polo seu capital escaso nos devanditos países, con pouca regulación financeira e agora van ter a competencia do capital abundante e menos caro dos capitalistas dos países desenvolvidos. Practicamente todos os traballadores dos países en desenvolvemento adoitan saír gañando, xa que se benefician tanto dos investimentos en deslocalización por parte dos países desenvolvidos, da maior posibilidade de emigrar a eles e de traballar en empresas que exportan a estes países. En especial, os que saen máis beneficiados nos devanditos países son os máis cualificados, xa que son os máis escasos e os que conseguen maiores aumentos dos seus salarios, tanto das empresas que deslocalizan como das que subcontratan coas empresas estranxeiras e das exportadoras.

É dicir, a meirande parte dos traballadores do mundo sae gañando como produtores, agás os traballadores menos cualificados dos países desenvolvidos, para os que cómpre buscar formas de compensación e axudalos a mellorar a súa formación, a reciclarse no mercado de traballo ou a anticipar a súa xubilación. Naturalmente, esta maior competencia non só é internacional, senón tamén local, xa que as empresas que saben como organizarse para aumentar os seus mercados globalizados e reducir custos poden implantarse noutros países desenvolvidos e apartar as empresas locais que non o fixeran. Agora ben, aínda existen moitos sectores dos países desenvolvidos que están pouco expostos á com- 
petencia, como a construción e o cemento, a enerxía e a meirande parte dos servizos, especialmente os de máis valor engadido, que están a medrar máis rapidamente que os expostos e que poden acoller traballadores afastados da industria e as manufacturas.

\section{QUE POLÍTICAS CÓMPRE DESENVOLVER PARA NON SER PERDEDOR?}

Só existe para os países desenvolvidos unha forma de facerlle fronte con éxito á globalización, que é aumentar a produtividade do traballo e a produtividade multifactorial e, xa que logo, o valor engadido do que se produce, o que permite reducir o seu prezo ou producir bens e servizos que outros non poden, co que se logra competir mellor en calquera mercado, por difícil que sexa. Este obxectivo pódese acadar, basicamente, de tres maneiras.

A primeira é mediante a aglomeración tanto da poboación, concentrándoa en cidades grandes cunha elevada densidade, como das empresas, aglutinándoas en clústers especializados por sectores de produción. Estas políticas de aglomeración producen elevados aforros de custos derivados das economías de escala e das economías externas e, asemade, aumentan notablemente a produtividade laboral e o PIB por habitante. Os mercados moi densos permiten aforrar custos nos desprazamentos, na utilización conxunta de infraestruturas, na procura de traballo, de subministradores, de compradores e de socios financeiros e empresariais, en compartir información e coñecemento e na transmisión da tecnoloxía.

Ademais, facilitan a localización de grandes centros de investigación e innovación, atraen en maior medida os traballadores nacionais e os inmigrantes, pero especialmente os máis cualificados, que buscan sempre mellores infraestruturas físicas, comerciais, culturais e mais educativas. Os estudos empíricos realizados recentemente atoparon unha elevada correlación entre a aglomeración, medida pola intensidade do emprego, e a produtividade total dos factores (TPF), así como entre a aglomeración e os niveis salariais. Dobrar a densidade da poboación en idade de traballar e do emprego supón aumentar entre o $4 \%$ e o $8 \%$ a produtividade anual e, xa que logo, os salarios. 
Basta con ver que rexións teñen un maior nivel de produtividade e de PIB por habitante da Unión Europea (UE) para comprobalo. Así, o centro de Londres, Bruxelas capital, Luxemburgo, Hamburgo e París, Illa de Francia, que oscilan entre un $280 \%$ e un $175 \%$ por riba da media da UE. Un exemplo extremo foi o do Xapón, país excéntrico, colocado durante décadas entre os principais mercados desenvolvidos e que, así e todo, logrou aglomerar a súa poboación e a súa produción en poucos grandes núcleos urbanos -en Tokyo acolle trinta e cinco millóns de persoas- e conseguiu converterse nun dos países máis ricos do mundo. Naturalmente, unha aglomeración excesiva leva a que os custos derivados da conxestión urbana e a deterioración medioambiental cheguen a devorar os aforros obtidos pola aglomeración -son os casos de México DF ou São Paulo.

A segunda forma de incrementar a produtividade é investindo en capital físico, especialmente en infraestruturas básicas, sobre todo as relacionadas coa enerxía, o medio natural e o transporte. Estas infraestruturas, tanto as tradicionais -estradas e autoestradas, liñas e estacións de ferrocarril, portos e aeroportos-, como as máis modernas -telefónicas, de satélites ou de banda larga, que son clave para o transporte a distancia das palabras, a información, as ideas e o coñecemento-, considéranse como «bens públicos». Isto non significa que non poidan ser financiadas directamente polo sector privado ou en cooperación entre o público e o privado, sempre que a devandita infraestrutura xere ingresos, como é o caso das autoestradas de peaxe, os portos ou os aeroportos.

Estas infraestruturas teñen un efecto importante e positivo sobre a economía dun país ou dunha rexión. Os investimentos públicos en infraestruturas resultan moi produtivos porque son unha parte esencial e necesaria do proceso de produción privado e porque aumentan o rendemento do traballo e das empresas en xeral.

Por unha banda, este tipo de investimentos reducen os custos do sector privado, tanto para establecerse como para desprazarse ou para subministrar os seus inputs esenciais. Ao reducir os seus custos, aumenta a rendibilidade do investimento privado, e por iso esta tende a aumentar co investimento público e non existe efecto crowding out ningún ou de desprazamento. Nos EE UU, os cálculos que se realizaron mostran que un dólar de investimento público en infraestruturas xera entre dous e catro dólares de investimento privado. 
Por outra banda, este investimento aumenta tamén o benestar dos cidadáns, que poden desprazarse con menor custo e en menos tempo. En contra da sabedoría convencional, conforme aumenta a renda dos cidadáns, o seu custo de oportunidade aumenta en similar proporción, co que todo o tempo que perda nos seus desprazamentos dun sitio a outro para acudir ao traballo cústalle cada vez máis, xa que o seu salario por hora é cada vez maior e grazas a esa nova infraestrutura aforra tempo, gaña máis renda porque lle pode dedicar máis tempo ao traballo ou logra máis tempo de lecer. Finalmente, a nova infraestrutura atrae e fai que se instalen empresas preto dela e que así aumente o investimento privado aínda máis, creando máis emprego, que xa medrara durante a construción da devandita infraestrutura.

Por todo isto, cómpre afirmar que as infraestruturas públicas do transporte mencionadas anteriormente, entre outras moitas básicas como o transporte e distribución da auga ou a enerxía, son esenciais para a converxencia de renda a longo prazo entre unhas poboacións e outras e entre uns países e rexións e outros. Non hai máis que observar a converxencia de renda entre as comunidades autónomas españolas que se acadou coa aceleración do investimento obtido dos fondos estruturais da Unión Europea nos últimos vinte e dous anos en España e o que aínda queda por facer.

A terceira forma de aumentar a produtividade dunha rexión ou país é o investimento en educación, formación, investigación, coñecemento, desenvolvemento e innovación. É dicir, o investimento en capital humano, que produce un maior retorno que ningún outro investimento e un meirande impacto na produtividade laboral e multifactorial, pola simple razón de que adoita mostrar rendementos crecentes, no canto de constantes ou decrecentes. As novas ideas e o coñecemento son, por unha banda, independentes da dispoñibilidade dos obxectos e, por outra, a diferenza dos obxectos, non son rivais.

É dicir, a utilización por unha persoa dun coche, un ordenador ou mesmo un átomo, que é a base dun obxecto, exclúe que outra persoa utilice este obxecto. Así e todo, as ideas poden ser aproveitadas por todo o mundo sen que a utilización por unha persoa exclúa as demais. Unha vez que se inventou o deseño dun chip, pode ser utilizado en miles de fábricas en todo o mundo sen necesidade de ter que ser inventado de novo ou reproducido cada vez que se realiza o obxecto: o propio chip. As ideas son independentes dos obxectos. Mentres que 
os obxectos precisan os átomos elementais para devir tales, as ideas son as instrucións necesarias para organizar os devanditos átomos e producilos.

Xa que logo, o crecemento económico pode ser sostible mesmo no caso de que os obxectos ou as súas materias primas sexan finitos, porque a través das ideas se poden atopar novas formas de organizar os átomos para producir máis obxectos cos mesmos átomos. De aí que, mentres que para unha tecnoloxía determinada ou un estado de coñecemento dado é razoable asumir uns rendementos constantes a escala nos factores de produción que son rivais -traballo, capital e solo-, as ideas non rivais fan que o coñecemento produza retornos crecentes a escala.

Agora ben, a idea dos rendementos crecentes a escala entra en conflito coa competencia perfecta, xa que a compensación de mellora das ideas antigas non rivais, de acordo co seu custo marxinal corrente, que é case cero, non produce premio nin incentivo ningún ao esforzo investigador para crear novas ideas. De aí que se introduza un sistema de competencia imperfecta no que cómpre protexer a consecución de novas ideas ou invencións cun período de explotación da patente en réxime de monopolio temporal que permita resarcirse do devandito custoso esforzo investigador, aínda que sexa posteriormente.

Cada nova idea ou coñecemento é creada polo investimento en capital humano e nas actividades de $\mathrm{I}+\mathrm{D}+\mathrm{i}$. Nos EE UU, os estudos empíricos mostran que os retornos ao investimento privado en $\mathrm{I}+\mathrm{D}$ son máis de dúas veces maiores que os investimentos en capital físico, e noutros países mesmo maiores. É máis, os devanditos retornos duplícanse se se teñen en conta os efectos «derrame» a outras empresas do mesmo sector. É dicir, o seu retorno social tende a ser moito maior que o privado. A rendibilidade privada deste investimento en $\mathrm{I}+\mathrm{D}$ depende dos anos de protección da patente. Como ningún sistema de propiedade intelectual ofrece unha protección total, hai un coñecemento que non se pode patentar e parte dese coñecemento xerado nunha empresa remata por estar dispoñible para outras empresas e outros innovadores, e ao final repercute nunha redución dos custos de $\mathrm{I}+\mathrm{D}$ para todos eles.

A rendibilidade e produtividade do investimento en capital humano é decisiva. Nos EE UU, un estudo estima que, entre 1950 e 1993, o maior nivel de educación, debido a un aumento en catro anos das taxas de escolarización, explica o $30 \%$ do crecemento do produto por hora traballada no devandito período. 
O restante 70\% é atribuíble ao aumento do stock de ideas nese país. Outro estudo mostra que o crecemento do investimento en $\mathrm{I}+\mathrm{D}$ é responsable desde un $40 \%$ a $60 \%$ do aumento da PTF.

Así mesmo, o maior e máis rápido uso das novas tecnoloxías da información e comunicación (TIC) nos EE UU, desde a metade dos anos noventa, permitiulles aumentar a súa produtividade a unha media do $4,5 \%$ anual fronte a só un $2 \%$ na Unión Europea. A contribución das TIC ao crecemento da produtividade total nos EE UU foi do $60 \%$ fronte a só o $40 \%$ na UE. Aínda que a media anual nos EE UU foi do $4,5 \%$, nos sectores produtores ou de usuarios de TIC a produtividade acadou os dous díxitos.

O caso máis paradigmático de investimento en capital humano foi o de Irlanda, que dedicou o seu investimento público, baseado nas transferencias dos fondos estruturais da UE, exclusivamente en capital humano e en $\mathrm{I}+\mathrm{D}+\mathrm{i}$, sen practicamente investir en capital físico e infraestruturas durante case vinte anos. A súa produtividade laboral e multifactorial medrou moito máis que a do resto da UE e agora é xa o segundo país con maior PIB por habitante medido pola capacidade adquisitiva, despois de Luxemburgo.

Pola contra, España investiu estas transferencias máis en infraestruturas que en capital humano. Irlanda investiu un punto porcentual máis de PIB ao ano que España en educación, medio punto máis de PIB ao ano en $\mathrm{I}+\mathrm{D}+\mathrm{i}$ e un cuarto de punto máis en TIC. Os resultados dunha e outra estratexia son os seguintes: o $85,7 \%$ da poboación de Irlanda, entre vinte e vinte e catro anos, completou o ciclo de educación secundaria ou maior, fronte ao 61,6\% de España. Irlanda produce anualmente tres veces máis graduados de ciencia e tecnoloxía, en termos relativos, que España, tres veces máis patentes na axencia de Europa (EPO) e seis veces máis patentes nos EE UU (USPO), en termos absolutos, que España. Dada unha media da UE igual a 100, a produtividade de Irlanda por persoa empregada é 107,1 e a súa produtividade por hora traballada é 135,6, mentres as de España son 92,8 e 102,8 respectivamente. Por último, o PIB de Irlanda medrou nos últimos dez anos ao 6,6\% de media anual e o de España ao $3,5 \%$, polo que, sendo 100 a media da UE, o seu PIB por habitante acadou, en 2007, o nivel de 146,5 mentres que o de España só o 104,7. 


\section{CUMPRE GALICIA ESTES TRES REQUISITOS MÍNIMOS PARA NON SER PERDEDORA?}

Analicemos agora a situación e as posibilidades de Galicia para mellorar as súas probabilidades de non ser unha comunidade perdedora na globalización ou de ser gañadora, tendo en conta os seus niveis de aglomeración, de investimento en capital físico e en capital humano.

En primeiro lugar, cómpre dicir que Galicia, en 2006, representaba o 6,2\% da poboación española, o que a situaba na quinta posición, tras Andalucía, Cataluña, Madrid e Valencia. A súa economía representaba o 5,1\% do PIB español, o que significa que, en termos de PIB por habitante, estaba un $17,5 \%$ por debaixo da media do conxunto español, é dicir, do 82,5\%. Representaba, ademais, o 5,9\% da superficie española e tiña unha densidade de poboación lixeiramente superior á da media española. A poboación ocupada en Galicia representaba o 5,9\% do total da empregada en España, proporción relativa máis baixa que a da súa poboación pero igual que a nacional e superior á do seu PIB. Estes datos relativos mostran que o problema económico de Galicia é debido fundamentalmente ao seu nivel relativo de produtividade, que é só do $86,7 \%$ da media española, e non ao seu nivel relativo de actividade e de emprego, que é igual que o do total nacional, aínda que, en todo caso, pode e debe tamén mellorarse.

\section{AGLOMERACIÓN}

No tocante ao seu nivel de aglomeración da poboación e da actividade, cómpre lembrar de antemán que Galicia partía dunha mala situación, xa que tradicionalmente fora unha comunidade cunha poboación moi dispersa, rural e que traballaba en minifundios, é dicir, que tiña todos os atributos necesarios para conseguir unha baixa produtividade laboral e, xa que logo, unha renda por habitante baixa, o que a converteu nunha comunidade con moitos emigrantes. Así e todo, nas últimas dúas décadas a poboación rural reduciuse dramaticamente, aínda máis do que xa era, e tamén envelleceu, mentres que a densidade aumentou notablemente nos contornos de Vigo e A Coruña e en varias cabeceiras de comarca. 
A densidade media da poboación de Galicia é lixeiramente superior que a de España -93 persoas por $\mathrm{km}^{2}$ fronte a 90 . Agora ben, esta densidade medrou moito no litoral e minguou notablemente nas zonas interiores. No litoral é hoxe de 304,6 persoas por $\mathrm{km}^{2}$, mentres que no interior só acada as 48,3. Máis aínda, entre Vigo, con 293300 habitantes, e A Coruña, con 243 300, representan xa o 19,4\% do total dunha poboación de 2767 000. As empresas tamén se aglomeraron arredor destas dúas cidades e existen xa varios clústers, dos que o máis importante é o do automóbil en Vigo. Non sería moi aventurado prognosticar que, segundo melloran as infraestruturas de transporte en Galicia, a concentración da poboación no litoral vai ser aínda moito maior, o que a pode converter nunha cidade que se estende entre Vigo e Ferrol, e que o interior continuará a despoboarse, agás nas fins de semana, nas que os que viven nas cidades farán de agricultores e gandeiros nas súas aldeas e vilas, como acontece xa en moitos países de Europa.

É dicir, a densidade ten mellorado moito, o que é moi positivo para a produtividade media de Galicia. O problema máis importante agora é o envellecemento da poboación, xa que para que unha comunidade prospere ten que medrar constantemente a súa poboación en idade de traballar, é dicir, entre os dezaseis e os sesenta e cinco anos, que é a que anda á procura activa dun emprego, a que consome e a que aforra e, xa que logo, a que crea PIB e aumenta o PIB por habitante. Neste sentido, esa última experimentou unha caída en termos absolutos, xa que era de 1813000 en 2000 e pasou a 1789000 en 2006. Podería ter caído moito máis se non fose polo aumento do número de estranxeiros, que pasou de 23700 a 71740 , no devandito período.

Cómpre lembrar tamén que existe unha correlación moi elevada entre éxito económico e atracción de inmigrantes estranxeiros, xa que estes, ao contrario que os españois, teñen unha mobilidade xeográfica absoluta e diríxense alí onde queira que haxa un posto de traballo dispoñible. Ademais, estes inmigrantes son todos xente en idade de traballar, o que fai que a súa taxa de actividade sexa alta e, xa que logo, a de emprego. De feito, teñen axudado a cubrir a metade dos postos de traballo xerados, malia ser só o $12 \%$ da forza laboral. No tocante a Galicia, a súa achega ao crecemento desta comunidade, entre 2000 e 2006, foi de 0,25 puntos porcentuais por ano, sobre un crecemento total medio del 3,1\% anual, fronte a unha media nacional de 1,3 puntos porcentuais por ano, dun 
total do 3,3\%. A súa achega ao crecemento da renda por habitante foi de 0,07 puntos porcentuais por ano, fronte a unha media en España de 0,05 puntos. A meirande parte dos estranxeiros son portugueses (13 224), seguidos dos colombianos (8063), os arxentinos e os brasileiros (6000 cada un). Pero o número de inmigrantes en Galicia constitúe só o 2,7\% da poboación total, mentres que no conxunto de España é o 9,3\%.

É moi interesante que Galicia sexa aínda unha comunidade de emigrantes, aínda que en forte descenso, xa que en 2006 emigraron só 3909 persoas (á Arxentina e o Brasil), fronte a unha entrada de inmigrantes de 22 948, que se establece nas grandes cidades galegas e no seu contorno. Outro feito paradoxal é que a migración interior, ao contrario que os inmigrantes, sae das cidades e vai cara ás vilas. En 2006, Vigo é a cidade que perde máis (1472), seguido de Ferrol (710) e da Coruña (336), pero estas persoas van a municipios intermedios, non pequenos. É probable que se trate de xubilados que retornan aos seus lugares de orixe.

\section{ACUMULACIÓN DE CAPITAL FÍSICO}

Verbo da acumulación de capital físico e infraestruturas, fíxose un estudo comparativo do capital neto acumulado das comunidades autónomas con cifras de 2004, no que Galicia mellorou o seu stock de capital de forma notable, especialmente en infraestruturas públicas, que medraron nun 5\% anual entre 1980 e 2004 fronte a un crecemento do PIB do 2,3\% anual e do PIB por habitante do $2,4 \%$ anual. Tamén experimentaron un forte aumento o capital privado, que medrou a unha media do $4 \%$ anual, e a vivenda, que o fixo ao $2,8 \%$ anual. Malia estes datos, o stock de capital neto de Galicia só acada o 4,9\% do total español, unha porcentaxe máis baixa que a da súa poboación, o PIB e o PIB por habitante.

Agora ben, existen grandes diferenzas no tocante aos distintos compoñentes do devandito capital neto total. Mentres que en infraestruturas públicas acada o $6,1 \%$ do total, case a mesma porcentaxe que a súa poboación, o seu capital neto non residencial é o 5,4\% do total español, o capital en TIC, do 5,3\%, lixeiramente superior ao do seu PIB, e o capital residencial é só do 4,2\%. Tamén é 
importante destacar que xa en 1985 o stock de capital de Galicia acadara o 5,3\% do total nacional, debido fundamentalmente ao residencial, que representaba o $40 \%$ do total; desde aquela ata 2004 , foi caendo lentamente ata o 4,9\%, que é só a media dos últimos vinte e cinco anos. Non obstante, desde 2004 ata hoxe, o investimento en infraestruturas e en vivenda foi tan importante que é moi probable que superara definitivamente a porcentaxe de 1985 .

Dentro do stock de infraestruturas públicas, que é o máis elevado en termos relativos, co $6,1 \%$ do total, tamén existen notables diferenzas. As ferroviarias representaban o $7,8 \%$ en 2004 , mentres que as urbanas caían ao $5,8 \%$, as portuarias ao $5,3 \%$, as hidráulicas ao $5,1 \%$, as viarias a só o $3,8 \%$ e, finalmente, as aeroportuarias ao $1,7 \%$. Outra forma de comparar o peso de Galicia no tocante ao investimento é analizar o seu fluxo no canto do seu stock. Pois ben, en referencia á distribución da formación bruta de capital fixo (FBCF) ou investimento anual por comunidades autónomas só existen datos de 2003, nos que se observa que o peso de Galicia no total da FBCF nacional é do 5\% na media entre 2000 e 2003. Dentro dela, superan esta porcentaxe a investida en agricultura, gandaría e pesca $(7,4 \%$ do total nacional), as actividades sanitarias, veterinarias e sociais (6,5\%), intermediación financeira (6,3\%) e administración pública $(6,3 \%)$. Por debaixo desta porcentaxe está o investimento en educación $(4,3 \%)$, industria $(4,2 \%)$, comercio $(4,2 \%)$ e en hostalería $(2,9 \%$ do total nacional).

En resumo, desde o punto de vista da acumulación de capital físico en Galicia, aínda que se ten prosperado moito, o crecemento foi menor que o da media española, co que a súa porcentaxe caeu en termos relativos, polo menos ata 2004. É notable o déficit de capital privado fronte ao público. Así e todo, hai aspectos positivos como o maior stock de capital en maquinaria e bens de equipo e menos stock en vivenda, como tantas outras comunidades autónomas, sobre todo as costeiras. Tamén é salientable que o peso do capital investido nas TIC é relativamente elevado, pero, como xa vimos máis arriba, é unha área onde cómpre facer o maior esforzo posible, xa que resulta moi rendible en termos de mellora da produtividade.

Non obstante, nestes cinco últimos anos, o investimento público foi enorme en Galicia. O Estado investiu, incluído o orzamento de 2008, 7641 millóns de euros e a Xunta de Galicia 6759 millóns de euros, é dicir, 14400 millóns con- 
xuntamente, o que aumentou o stock de capital neto de Galicia en 2004 nun $8,5 \%$, o que supón 1,7 puntos porcentuais ao ano, co que o devandito stock xa acada hoxe a mesma proporción do capital nacional total que a súa poboación. De seguir nos vindeiros anos esta tendencia, a produtividade de Galicia aumentará notablemente.

\section{ACUMULACIÓN DE CAPITAL HUMANO}

No tocante á acumulación de capital humano, Galicia ten debilidades. Se analizamos o nivel de estudos da poboación maior de dezaseis anos, está só no $95,6 \%$ da media nacional. Por unha banda, a porcentaxe de anos de escolarización en Galicia era, en 2000, de 7,7 anos, mentres a media de España estaba en 8,2 . Por outra, en 2000 , a poboación adulta -vinte e cinco anos ou máis- analfabeta era na comunidade autónoma do $2,5 \%$, fronte a unha media nacional do $3 \%$; con educación primaria era do 50,3\%, fronte ao 41,9\% de España; co primeiro ciclo de secundaria era en Galicia do $22,2 \%$ e no resto do Estado do $24,6 \%$; co segundo ciclo de secundaria era do $14,6 \%$, fronte ao $17,1 \%$; con primeiro ciclo de educación universitaria, o 5,2\% contra o 6,3\%; e con segundo ciclo universitario Galicia tiña unha media do 5,4\% e España un 7,1\%; as diferenzas maiores danse nos niveis superiores.

Así e todo, as cifras en 2005 melloran bastante e mostran que entre o total da poboación galega hai un $2 \%$ de analfabetos, porcentaxe menor que o 2,2\% nacional; un $34 \%$ tiñan estudos primarios, fronte a un 31,8\% de media española; un $43,5 \%$, estudos secundarios, mentres que a media nacional era do $44,1 \%$; e un $20,6 \%$ de galegos tiñan estudos terciarios, fronte a un $22 \%$ de media nacional. Agora ben, só un $12 \%$ tiñan estudos superiores, mentres que a media nacional era do $16 \%$. Os empregados con elevada cualificación eran o $28,6 \%$ do total en Galicia, fronte ao 30,8\% de España; e os ocupados con estudos superiores acadaban o $31 \%$ na comunidade autónoma e o $32,2 \%$ no Estado.

Estas diferenzas non son moi elevadas, pero si o é o desaxuste que existe entre oferta e demanda de emprego en Galicia. Sendo a media nacional de 100, o desaxuste en Galicia era de 84,9. Un 87,5 entre os empregados de alta cualificación e un 84 entre os de baixa. Finalmente, os parados con estudos superiores en 
Galicia eran un $33,8 \%$ do total dos activos, fronte a un $23,2 \%$ da media nacional; máis de dez puntos menos. Así mesmo, a taxa de paro entre as persoas con estudos terciarios era do 10,6\%, fronte ao 6,8\% de España; maior que a media das persoas que tiñan estudos secundarios, co $10,1 \%$, e mesmo menor que a que tiñan as persoas con educación primaria.

Malia estes datos, a rendibilidade social de investir en educación en Galicia é elevada, xa que acada un $11,3 \%$, é dicir, máis de dous puntos porcentuais superior á rendibilidade de investir en capital físico privado, e lixeiramente maior que a do investimento en infraestruturas. De aí que sexa preciso facer un grande esforzo neste eido, xa que a experiencia doutros países mostra que, a maior nivel xeral de educación, maiores son tamén as probabilidades de que se creen máis empresas e que haxa un maior número de empregados con niveis de educación máis elevados.

En Galicia había, no curso 2004-2005, 85000 estudantes universitarios matriculados en primeiro e segundo ciclo nas súas tres universidades, entre un total de 2,7 millóns de habitantes, o que representa un 3,1\% da poboación total de Galicia, fronte ao 3,3\% do total español. É dicir, o 5,85\% dos universitarios españois eran galegos, só 0,25 puntos porcentuais menos que o índice de participación da poboación galega no total de España. Ademais, a especialización das universidades galegas é maior nas ciencias experimentais, sociais e xurídicas que en humanidades, saúde ou ensinanzas técnicas, o que resulta positivo de cara ás actividades emprendedoras e tamén para a difusión da investigación e a tecnoloxía. O número de doutorados representaba o 5,2\% do total nacional; os gastos universitarios en $\mathrm{I}+\mathrm{D}$ acadaban o $6,4 \%$ do total do Estado; o número de persoal que traballaba en actividades de $\mathrm{I}+\mathrm{D}$ representaba o $7 \%$ e o de investigadores $7,8 \%$ do total español.

Unha análise recente dos niveis de difusión da nova economía do coñecemento nas comunidades españolas, utilizando un indicador sintético con catro bloques -produción e utilización na industria, produción e utilización nos servizos, gasto en $\mathrm{I}+\mathrm{D}+\mathrm{i}$, e desenvolvemento da sociedade da información e Internet- e vinte e nove variables, demostra que Galicia se sitúa no posto número nove entre as dezasete comunidades autónomas españolas, e reflicte resultados por debaixo da media nos catro bloques. No bloque industrial, presenta un valor de 10,73 fronte a unha media nacional do 21,57; no de servizos acada o 25,11 
fronte ao 36,20 de media nacional; no de gasto en $\mathrm{I}+\mathrm{D}+\mathrm{i}$ sobe ao 44,85 fronte ao 46,81 da media nacional; e no da sociedade da información e Internet está nun 86,05 fronte a unha media nacional do 88,90 . En conxunto, Galicia presenta unha media de 31,94 fronte á nacional de 40,20. Aínda que cómpre recoñecer que Galicia non está mal clasificada en termos de gasto de $\mathrm{I}+\mathrm{D}+\mathrm{i}$ no total nacional, xa que inviste un pouco máis do $0,75 \%$ do seu PIB nestas actividades, non obstante, a súa balanza de pagos tecnolóxica é extraordinariamente deficitaria, non porque as importacións sexan moi elevadas -o que sería moi positivo-, senón porque as exportacións son moi pequenas.

Os investigadores galegos publicaron 1755 traballos científicos en revistas universitarias nacionais, entre 1996 e 2001, e 7022 en revistas internacionais, o que sitúa a Galicia, na clasificación no conxunto das comunidades autónomas do Estado, en publicacións por habitante nos postos número once e oito, respectivamente. No tocante a citas por publicacións, as universidades galegas acadan as 4,86 citas por documento publicado, fronte a 7,30 das universidades catalás. Así e todo, en canto ao número de solicitudes de patentes, as universidades galegas, malia non teren unha Politécnica, como Madrid, Cataluña ou Valencia, conseguiron solicitar 77 patentes na OEPM nacional, entre 1999 e 2004, un $8 \%$ do total nacional, e as solicitudes de patentes europeas (EPO) acadaron un $8,7 \%$ deste total.

Cada profesor universitario ten dereito a recibir ata seis «tramos» polos sexenios de investigación da CNEAI -o que lles reporta un complemento salariale pode obter tamén financiamento do Plan Nacional de I+D para realizar a súa tarefa investigadora. Nas universidades galegas só se adxudicaron 0,94 tramos por profesor, fronte a unha media nacional de 1,15; ademais, un $40,3 \%$ dos profesores nunca solicitaron estes tramos, fronte a unha media nacional do $34 \%$. No tocante ao financiamento, as universidades galegas conseguiron unha media do $2,18 \%$ do total concedido a todas as universidades do Estado, o que resulta unha porcentaxe relativamente baixa. Na clasificación das cincuenta universidades públicas, a de Santiago ocupa o posto dezanove, a de Vigo o vinte e cinco e a da Coruña o vinte e oito, é dicir, están en conxunto por debaixo da media.

Galicia ten gastado moitos recursos en innumerables parques tecnolóxicos, pero lamentablemente estes teñen desenvolvido moi pouca tecnoloxía e menos aínda empresas realmente tecnolóxicas. Moitos foron meras operacións inmobi- 
liarias de creación de parques empresariais. O lóxico sería concentrar todo o esforzo en ter só dous ou tres, moi ben equipados, pegados ás súas universidades e que actuaran en rede entre elas e as empresas. En 2004, as universidades galegas conseguiron crear quince novas empresas deste tipo -spin-offs-, dun total de 479; só un 3,1\% do total, e unicamente o fixo a de Santiago de Compostela.

Un último elemento fundamental é a creación de empresas. Se se inviste en capital humano e en $\mathrm{I}+\mathrm{D}+\mathrm{i}$, a probabilidade de aumentar as actividades emprendedoras e a creación de novas empresas é moito máis elevada. En 2007, Galicia creou 6670 empresas, fronte ás 143630 do conxunto nacional, é dicir, só un $4,6 \%$, porcentaxe menor que o peso do seu PIB, que é do 5,1\%. Esta cifra indica que cómpre facer un notable esforzo por fomentar as actividades emprendedoras nas escolas e universidades.

\section{A IMPORTANCIA CRECENTE DUNHA POLÍTICA MICROECONÓMICA, AUTONÓMICA E LOCAL}

Os procesos de integración e globalización están a limitar, cada vez máis, a posibilidade de que os países poidan desenvolver políticas macroeconómicas -monetaria e fiscal- autónomas. Tal é o caso dos países da Unión Económica e Monetaria Europea, que centraliza a política monetaria no Banco Central Europeo e establece un xustillo, necesario, para a política fiscal a través do Pacto de Estabilidade e Crecemento que lles dá moi pouca marxe ás expansións fiscais autónomas, e especialmente se son, como ata o de agora, procíclicas. A libre circulación de capitais e persoas dentro da Unión, establecida polo Mercado Único, tamén está a impoñer, paseniño, unha certa harmonización dos tipos impositivos en toda a Unión Europea, xa que, de non facerse, os países con tipos máis altos perderán, devagar, capitais, empresas e persoas con renda elevada que poderán fixar a súa residencia fiscal en países, como Luxemburgo, que teñen tipos impositivos moi baixos sobre a renda das persoas físicas, a renda de sociedades e os dividendos e intereses das rendas de capital.

A consecuencia destes procesos que limitan fortemente a política macroeconómica autónoma, porque a centralizan ou harmonizan en instancias superio- 
res, é que os gobernos se ven cada vez máis limitados para desenvolver exclusivamente políticas microeconómicas de oferta, que, ademais, se poden facer, ás veces con maior eficiencia, nas instancias autonómicas e mesmo locais que nas nacionais. Segundo avanzan a globalización e a integración económica, aumenta, por unha banda, o desenvolvemento de políticas, coordinadas a nivel mundial, naqueles aspectos da globalización que teñen efectos «derrame» sobre o resto do mundo, como son o medio natural, o terrorismo, a sanidade, a migración, o contrabando de seres humanos, de drogas ou de armas e as crises financeiras. E, por outra banda, tamén aumenta, aínda que resulte un paradoxo, a descentralización política, dentro dos Estados-Nación, nas comunidades autónomas e nas cidades, xa que para facer moitas das políticas microeconómicas e microsociais necesarias de xeito eficiente, cómpre realizalas o máis preto posible e en contacto permanente cos cidadáns e as empresas.

Todos estes argumentos outórganlles cada vez máis responsabilidade aos gobernos autonómicos ou locais, á hora de conseguir que as súas comunidades, comarcas ou cidades -ou, o que vén sendo o mesmo, as persoas, institucións e empresas que residen na súa demarcación- sexan competitivas e, xa que logo, non resulten perdedoras neste proceso de crecente globalización e integración da economía mundial e de maior competencia entre as empresas, os países e as comunidades. É dicir, para que unha comunidade autónoma poida resultar triunfadora, a actuación do seu goberno debe ser cada vez máis microeconómica e máis próxima ao tecido empresarial produtivo da súa demarcación.

Neste marco máis globalizado e competitivo, como se pode facer unha política autonómica que consiga mellorar o desenvolvemento da renda e riqueza desa comunidade? Cómpre lograr que as empresas sexan máis competitivas, para que poidan manter e aumentar as súas cotas de mercado e expandirse por outras comunidades e países. É dicir, desde os gobernos autonómicos hai que facer un maior esforzo para crear un clima propicio ao investimento empresarial e á mellora do seu capital humano e tecnolóxico.

Tamén cómpre intentar adiantarse aos acontecementos que se aveciñan e axudarlles ás empresas da comunidade a especializarse, internacionalizarse e a concentrarse, tanto en menos plantas como territorialmente en clústers, para obter maiores economías de escala e economías externas. É dicir, cómpre incentivar as empresas para que acaden maiores aforros de custos, ben aumentando a 
súa escala, ben mercando outras ou ben internacionalizándose. É preciso estimular a creación de clústers de empresas dun determinado sector, nunha zona ou área que estea moi ben comunicada, para conseguir aforrar custos e, ademais, contribuír a que cooperen en centros conxuntos de investigación e desenvolvemento tecnolóxico, de formación de man de obra especializada, de compras e de distribución nacional e estranxeira, o que aumentará a produtividade e a calidade dos seus procesos de produción e distribución.

Ademais, cómpre mellorar o capital humano, investindo fortemente en centros de excelencia universitarios que faciliten a investigación, innovación e desenvolvemento sectoriais e nos que participen conxuntamente as universidades, as empresas e as entidades financeiras autonómicas. Tamén hai que intentar que desapareza toda barreira de entrada ou saída en calquera sector e atraer outras empresas nacionais e estranxeiras para que poidan establecerse libremente nesa comunidade e competir coas actuais. Finalmente, cómpre incentivar ao máximo o espírito emprendedor dos galegos, especialmente dos máis novos, para que creen empresas no país, no canto de andar á procura dun posto de traballo noutras comunidades autónomas ou no estranxeiro e, se xa marcharon, conseguir atraelos de novo para que retornen ou establezan negocios en Galicia.

Todo isto require unha política económica de ámbito galego que sexa selectiva, é dicir, que aposte por algo concreto, por aquelas determinadas zonas do territorio que teñen maiores posibilidades de éxito porque están mellor integradas, por ter unha maior aglomeración da poboación que permita o desenvolvemento dun mercado máis amplo e, xa que logo, a unha maior escala, ou por ter mellores dotacións de capital físico e humano ou mellor acceso aos mercados internacionais. Tamén hai que protexer aquelas empresas e sectores que mostren maiores vantaxes competitivas e máis dinamismo e que teñan máis capacidade para competir e liderar no longo prazo. Cómpre, así mesmo, apostar polo desenvolvemento do capital humano para que se formen adecuadamente empresarios, traballadores, científicos e intelectuais que sexan os futuros líderes do progreso político, empresarial e económico de Galicia.

Tanto na vida económica como na política ou social cómpre ser valente e arriscarse. A política económica parte orixinariamente dunha restrición fundamental: os recursos públicos dispoñibles son sempre escasos e insuficientes para conseguir un crecemento equilibrado ou para satisfacer todas as demandas das 
familias e das empresas; de non ser así, non existiría a devandita política. Dado que os recursos son escasos, caben dúas opcións: unha, que é a que máis se ten dado tradicionalmente en Galicia e que aínda predomina en parte dos políticos, consiste en «ir regando» equitativamente, con pequenas cantidades de recursos orzamentarios, todos os lugares da comunidade, sen ter moito en conta os seus custos relativos, a rendibilidade, se están a despoboarse ou non -dados os recentes movementos territoriais da poboación e a concentración nas zonas urbanas costeiras- ou a súa capacidade para competir; esta é unha política de moi curto percorrido e herdeira do antigo caciquismo, que hoxe non ten razón de ser ningunha. A outra opción consiste en apostar por algo e arriscarse; toda actividade humana, e aínda máis a económica, consiste en elixir entre varias opcións, arriscarse por unha fronte á outra, aínda que nos equivoquemos, porque se sabe que, se non se corren riscos, non se pode prosperar. Velaí onde xogan un papel fundamental a información e o coñecemento, xa que canto maior sexa a información e coñecemento que teñamos sobre un tema, menos riscos teremos de equivocarnos e menores serán as consecuencias no caso de facelo. Así pois, na información e no coñecemento están as claves do éxito de calquera política económica ou empresarial. Os países e as comunidades nos que os cidadáns acceden a unha educación e formación mellores teñen unha maior capacidade para tomar as decisións máis axeitadas, porque manexan e asimilan mellor a información, de aí a importancia de apostar polo capital humano e a necesidade de conseguir núcleos de excelencia e de calidade na administración, no ensino, nas universidades e nas empresas máis dinámicas. Só así se conseguirá que Galicia prospere e sexa un país florecente, con maior benestar para todos os seus cidadáns. 